\title{
The Intersection of Self and Social Identity in Heritage Brand Destination
}

\author{
NORFARDILAWATI MUSA \\ Open University Malaysia \\ SHUHAIDA MD NOOR \\ Universiti Sains Malaysia
}

\begin{abstract}
The recognition from the United Nations Educational, Scientific and Cultural Organisation (UNESCO) on heritage tourism draws destination tourists both international and local. Lenggong Valley (LV) is well-known with the Perak Man and archaeological sites. Since its discovery and inscription as one of the UNESCO world heritage sites in 2012, relevant planning has been established to develop the area as part of tourism destinations in Malaysia. Developing a brand destination is intricate in view of its multifaceted structure and multiple stakeholders with different interests that a destination possessed. The early stage for the identification of destination-brand identity is crucial in ensuring the involvement of its stakeholders, particularly the residents. The key reason offered by most of the literature reviews for destination branding is, this group plays an important role in providing destination experiences to the tourists. The focus of this research is to give an overview and discuss how the self and social identity that underlie the resident's evaluation are intersected, which affects their interpretation of destination-brand identity. Adopting a qualitative method and guided by the stakeholder and social identity theories, the data collection was conducted in two phases - (i) in-depth interviews; and (ii) focus group interview (FGI). The participants were purposively selected consisting of the headmen and some representatives of the female residents to represent the residents' perspectives. Data were analysed using the 6-step thematic analysis. The findings revealed that residents' conceptualization of the Lenggong Valley World Heritage Site's identity revolves around the intersection between their self and social identities.
\end{abstract}

Keywords: Heritage tourism, stakeholders, destination branding, brand identity, social identity theory.

\section{INTRODUCTION}

Residents as internal stakeholders play crucial roles in determining the success of a destination brand. One of the most important processes in destination branding is to determine its brand identity by multiple 'owners' including the residents. Brand identity is the cornerstone of brand strategy and brand building (Aaker, 2014). The brand owners need an articulated description of the aspirational image for the brand, and what they want the brand to stand for in the eyes of the target audience for the brand success.

The interdependent, multidimensional and multiple nature of internal stakeholders for destination makes the process of identity development very complex due to different interests and values (Anholt, 2007; Hernandez et al., 2007). Currently, there is a dearth of knowledge on how to identify values that can be concurred upon by these multiple stakeholders, and to reflect them in the destination brand identity. To fill the gap, this research investigates the conceptualisation of destination brand identity by the residents as a process of interpreting and communicating their personal and social values. 
The core of branding strategies is the identification and development of brand identity (Aaker, 2010). Brand identity refers to the set of unique associations that represents what the brand stands for which encapsulates the brand owners' promise of value or benefit to the customers (Keller, 2012). A brand may have numerous elements associated with it, however, only the most salient among these associations form a brand's identity (Keller, 2012). These salient elements act as the identifying factor and differentiate it from the competitors (Aaker, 2010; Keller, 2012). Identifying clear brand identity and communicating it effectively to the target consumers are key processes of successful branding (Aaker, 2010), as brand identity helps consumers in their meaning making process. A distinctive, relevant and consistent identity provides added value to the consumers and helps the brand to generate market preference and command a price premium (Anholt, 2005; Boisen et al., 2010; King \& Grace, 2005; Park et al., 2009).

Destination has multiple internal stakeholders whose values and interests are important (Konecnik \& Go, 2008; Singh \& Hu, 2008). Failure to address the different (Hall \& Jenkins, 1995) will result in a difficulty to achieve consensus about the core identity of a destination brand and cooperation in the future direction and development of a destination. Recent literature emphasises the significance of internal stakeholders, particularly the residents, in the decisions-making process at tourist destinations (Avraham \& Ketter, 2008; Dinnie, 2011; Fyall, 2011). The residents through interactions and engagement with tourists have been shown to influence the authenticity of experience (Blain et al., 2005; Hankinson, 2009; Jamal \& Gezt, 2005; Khanna, 2011; Morgan et al., 2011; 2014) and tourist satisfaction (March \& Wilkinson, 2009) at the destination. The stakeholders' involvement ensured the sustainability of the destination (Dredge, 2006; Lemmetyinen \& Go 2009; Pforr, 2006). Guided by the theories of stakeholders and social identity, this research explores the following research question (RQ):

- What are the identities and values of archaeological sites perceived by the residents and how do they interpret the identity(s)?

This research is conducted in the Lenggong Valley World Heritage Site (LVWHS). As the newly inscribed world heritage, stakeholders' interpretation of the place should be considered in developing its brand identity to avoid any conflict that could jeopardize the sustainability of the site as a tourism destination (Lemmetyinen \& Go, 2009; Pforr, 2006).

\section{Destination Branding}

\section{LITERATURE REVIEW}

The existing brand development models and frameworks used to develop brand identity for consumer products and services have not been tailored to address the complex nature of multiple stakeholders' involvement faced by tourism destinations. The conceptual models and the practical applications of destination branding are developing at different speeds so far. A general theoretical approach underpinning destination branding has been developed by researchers such as Kotler and Gertner (2002) and Hankinson (2009) but is guided by classical branding theory which does not address all the complexity in destination branding due to different fragments of stakeholders (Palmer \& Bejou, 1995). The stakeholder's involvement is important to reflect their values leading to improved product and tourist experience (Cosma, Urcan \& Bota 2010). 
Besides, past research has mainly focused on destination brand image rather than brand identity (Gertner \& Kotler, 2011; Morgan et al., 2014). The concept of brand identity differs from the concept of brand image. Brand identity refers to the quality and values perceived by the brand owners, whereas brand image refers to the values quality and values perceived by the tourists. The images that are formed by tourists are not necessarily the ones that originate from or aspired by the brand owners. Destinations, however, have many brand owners whose consensus are crucial to avoid future conflicts of interest and thus pose a threat to the success of a tourism destination (Gould, 2011; Morgan et al., 2011; Sheehan et al., 2007).

Destination branding needs a broader and more holistic set of values from the perceptions of stakeholders to facilitate a more viable and sustainable destination brand identity. Developing and implementing a destination brand identity by engaging the values and identity perceived by the stakeholders is the critical missing link in research on destination branding (Wheeler, Frost \& Weiler, 2011). The complexity and problematic destination concept are the reason for the underdeveloped brand identity discussion in a destination context. Although it may be time consuming and difficult to bring the stakeholders to collaborate and communicate their perception and understanding of the identity and value of a destination, still, it is a fundamental and critical process.

\section{Destination Brand-Identity}

According to Keupp et al. (2009), identity is formed through the progressive adjustment of the self-perception and social perception. While Erikson (2011) believes that identity is the perception of a person to be autonomous and holistic. Despite all their experiences and the conflicts associated with them, he has introduced two constitutive characteristics of identity namely continuity and consistency.

Brand identity can be considered as representations that help to differentiate a brand from its competitors based on the brand positioning statement (Balakrishnan, 2009). In recent literature, there is constant debate on the concept of brand identity. Most of the authors in the field of business and management were not able to accept a standard definition for this concept. As for this reason, a common understanding of what brand identity refers to has been proposed - a theoretical concept that should be provided from the perspective of the supplier (Konecnik \& Go, 2007). Kapferer (2012) clearly defines brand identity as something that we must know about ourselves before we identify how others perceive us (Merkelsen \& Rasmussen, 2016).

The brand management scholars agree that every brand has an identity and that every brand identity contains an essence (DNA or kernel) that is the very core of the brand (Ind, 2003). The brand essence is most often an abstract idea or sentence summarising what is the heart and soul of the brand (Aaker \& Joachimsthaler, 2002; Keller, 2003). Brand identity must express the vision and uniqueness of the brand. If the brand identity is unique, distinct and a clear expression of what the brand is all about, it can create the basis of a solid, coherent and long-lasting brand and be the driver of all brand-related activities.

\section{a. Model of Brand Identity}

In the process of brand formation, the structure of brand identity can be analysed from several perspectives according to the existing models proposed by prominent authors. Most of the brand identity models applied in the branding process still widely used by researchers. 
The models have been developed since the 1980's and are still relevant today (Petek \& Ruzzier, 2013). However, this study applied the brand identity model developed by Kapferer (2012) to guide the process of developing an identity for LV. There are six elements suggested for a brand identity that need to be identified for brand identity development in Kapferer's prism. They are physical attributes, personality, relationships, culture and self-image as shown in Figure 1.

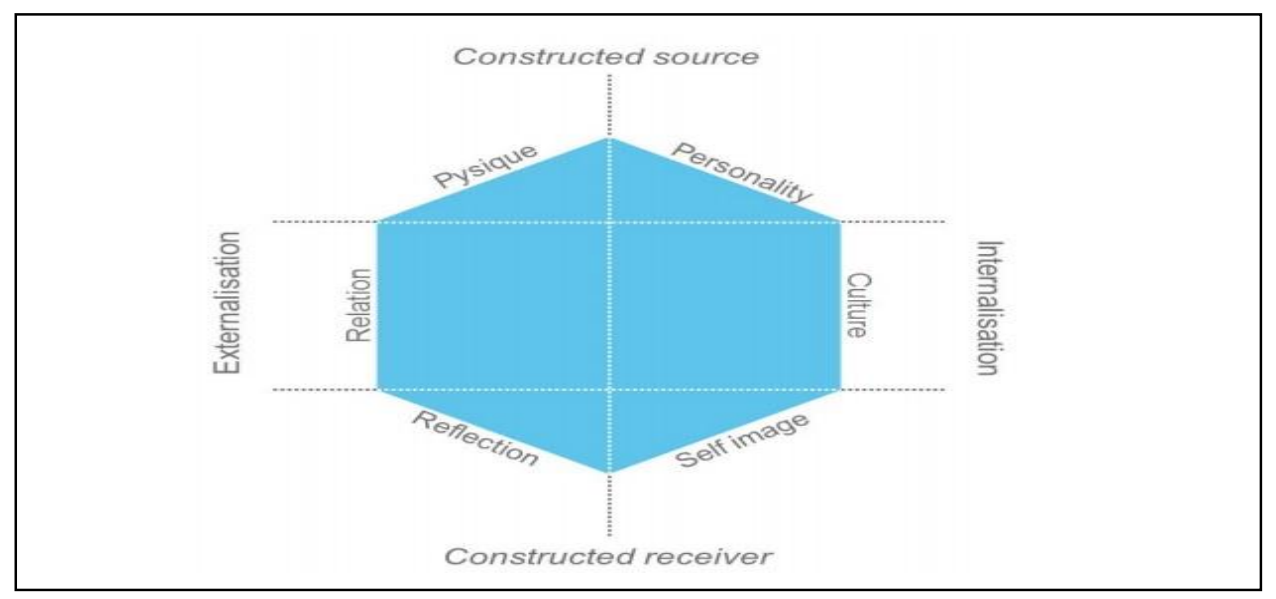

Figure 1: Kapferer's Identity Prism

Source: Kapferer (2012) in The New Strategic Brand Management

These six facets are interrelated and can establish a well-designed brand identity. Besides, this model allows marketers to examine and comprehend the various aspects of the brand (Mishra, 2010). In destination branding, Kapferer's prism helps to analyse different facets possesses by a destination that can be developed into a strong brand identity (Sisouvong, 2018).

In destinations, brand identity relates to how brand owners want the destination to be perceived, encapsulating the features and beneficial attributes, as well as the symbolic, experiential, social, and emotional values of the place which are imbued in the brand (Kavaratzis \& Ashworth, 2005). Destination brands are designed to create a unique and appealing identity conveying values that are consciously or intuitively linked to that destination's sense of place (Williams, Gill \& Chura, 2004). Yet this interrelationship and the role of values in linking destination brand identity and sense of place tends to be overlooked in the destination branding literature (Gnoth, 2007).

The formation of destination identity should go beyond the traditional approaches focusing solely on the perspectives of visitors, but rather should be viewed as a process of cocreation and co-production between visitors and the multiple owners (Berrozpe et al., 2017; Lew, 2017).

\section{Destination Stakeholders and Brand Identity}

In developing a destination brand identity, participation and collaboration with the stakeholders should start at the early stage (Beritelli, 2010; Waayers et al., 2012) for the identification of core values and the development of a destination's brand. The process of brand development between destination and other products/services is completely different in terms of the owner. Unlike other products/services available in the market, a tourist destination has no single owner or authority to determine the destination brand. Every 
stakeholder has the possibility to influence the future of a destination brand because they are also the providers of the main structure for tourism and products that will be offered and involved directly in the destination activities (Bornhorst et al, 2009; Morgan et al, 2003).

The success of destination branding depends a lot on its stakeholders (Beritelli \& Laesser, 2011; McComb et al., 2016). Other than profit, stakeholder's involvement provides a competitive advantage in terms of efficiency or improved profitability, and capable of preventing undesirable behaviour (Hutton, 2002). Stakeholder identification is the first step in developing a strong and coherent brand. Once the stakeholders are identified, they should be included in the tourism development process, particularly in brand management. As Donaldson and Preston (1995) suggested, all stakeholders do not need to be involved equally in the decision-making process, but all interests should be identified and understood, especially, the residents that are directly affected in the branding process.

\section{Stakeholder Theory and Brand Identity}

In the stakeholder theory, power is one of the attributes considered critical for understanding 'who and what really counts' (Mitchell, Agle \& Wood, 1997). In the study conducted by Marzano and Scott (2006), different opinions among the stakeholders on destination branding resulted in the concepts of collaboration and power to produce a successful destination tourism plan. The unity and cooperation among the stakeholders on destination branding is critical in achieving uniformity or consistency of destination brand values through a set of shared meaning (Morgan et al., 2003).

The residents act as little ambassadors who are directly involved with the experience offered to the tourists. Failure to engage them in destination branding will only create conflict that results in the inability to fulfil the promised and publicised experiences to tourists. The tourism literature has shown consistency in considering destination branding as collaborative efforts between the stakeholders (Balin, 2001; Deslandes, 2003; Im, 2003; Kaplanidou \& Vogt, 2003; Morgan, Pritchard \& Piggot, 2002), because they act as a contributor of unofficial information through word of mouth - which considered as an effective source of information (Baker, 2007; Kuenzel \& Halliday, 2008; Lin \& Sung, 2014; Mazzarol, Sweeney \& Soutar, 2007).

The concept of collaboration is a process of considering each stakeholder group without one being given priority over the others (Sautter \& Leisen 1999). Collaboration in tourism development is a "community-based tourism planning of an inter-organisational, community tourism domain to resolve planning problems of the domain and/or to manage issues related to the planning and development of the domain" (Jamal \& Getz, 1995, p. 188). The theory also indicates the need to identify and understand the interests of all stakeholders in developing destination brand (Boatright, 2002; Jamal \& Getz, 2000; Kennedy \& Augustyn, 2014; Sheehan \& Ritchie, 2005).

\section{Theory of Social Identity (SIT)}

SIT refers to how people perceive and categorise themselves based on the groups that have been designed and constructed by society (Abrams \& Hogg, 2006; McLead, 2008; Tajfel, 2010). Self is said to be as reflexive because it can take itself as an object and can categorise, classify or name itself in particular ways in relation to other social classification - selfcategorisation (Guan \& So, 2016; Stets \& Burke, 2000). Hitlin (2003) and Joas (2000) believe that self is the key element and conscious essence that forms a meaningful relationship with 
any social entities. Because of the dynamic concept of self, it has the potential to respond with the surroundings and change into something that self-favour.

Individuals form self-conceptions based on two elements: (i) personal or self-identity; and (ii) collective identity. Personal or self-identity refers to our unique, personal qualities such as our beliefs, abilities and skills, etc. The collective self includes all the qualities that arise from being part of a group such as a society, culture, family, groups or clubs (Ashmore, Deaux \& McLaughlin-Volpe, 2004; Reed et al., 2012). For example, one may identify oneself as a Malaysian, Kelantanese, psychologist or tourist.

In this theory a person has several selves that correspond to the widening of circles of a group membership. Different social contexts may trigger an individual to think, feel and act based on his/her personal, family or national "level of self" (Turner et al., 2000). An individual also has multiple "social identities" - the individual's self-concept derived from perceived membership of social groups (Guan \& So, 2016; Hogg \& Vaughan, 2002). In other words, it is an individual-based perception of what defines the "us" associated with any internalised group membership (Bergami \& Bagozzi, 2002; Bhattacharya \& Sen, 2003; Fujita, Harrigan \& Soutar, 2018; McAlexander, Schouten \& Koening, 2002; Reed et al., 2012). This can be differentiated from the concept of personal identity which refers to self-knowledge derived from the individual's own unique attributes or personality. By internalisation of the social categorisation which defines a group's memberships, the person achieves specific social identities which may either have a positive or negative value.

There are two groups based on social comparison process - (i) in-groups which refer to the persons who are similar to the categorised self; and (ii) out-groups, the people who differ from the categorised self (Hogg \& Abrams, 2006; McLead, 2008; Parkinson et al., 2005; Reed, 2004). The group membership creates in-group or self-categorisation and enhancement in ways that favour the in-group at the expense of the out-group. Turner and Tajfel (2015) also identified three variables that contributed to the emergence of in-group favouritism or the formation of the in-group and the out-group. They are social categorisation, social identification and social comparison.

In developing a brand, there are studies that collectively provide evidence that individuals integrate brand associations into their self-concept on the basis of the centrality of the identity and the level of symbolism the brands hold for an identity (Harmon-Kizer, Kumar, Ortinau \& Stock, 2013). Consumers construct their self-concepts partly from the brands they use, and in the process form self-brand connections (Escalas \& Bettman, 2005). The connection only needs to occur between the brand and one aspect of the self, with more schematic aspects of self-resulting in stronger connections (Escalas, 2004). This is due to the multiple identities owned by the consumers, and it is unknown how a consumer decides which aspect of their self-concept is more schematic in the formation of brand connections.

Identity centrality is defined as the importance of psychological attachment individuals place on their identities (Settles, 2004), and it has been shown to organise the selfhierarchy which then leads to greater identity commitment (Settles, 2004). Centrality has been found to be the single most important predictor of sustained role-related behaviour (Laverie et al., 2002). With the presence of multiple identities among stakeholders, it can be predicted how the stakeholders associated themselves with any brand that is going to be developed, and to what extent the brand supports their values and self-expression. In this light, the DMO of a tourism destination must consider how stakeholders identify and evaluate a place before any decision is made to develop the brand identity. This process according to 
Settles (2004) and Martire et al. (2000) is akin to identity negotiations, whereby individuals negotiate potentially conflicting identities within their self-hierarchy.

\section{Theoretical Framework}

Based on these theories as well as the concepts introduced, the following framework (Figure 2 ) is created to answer the RQ developed:

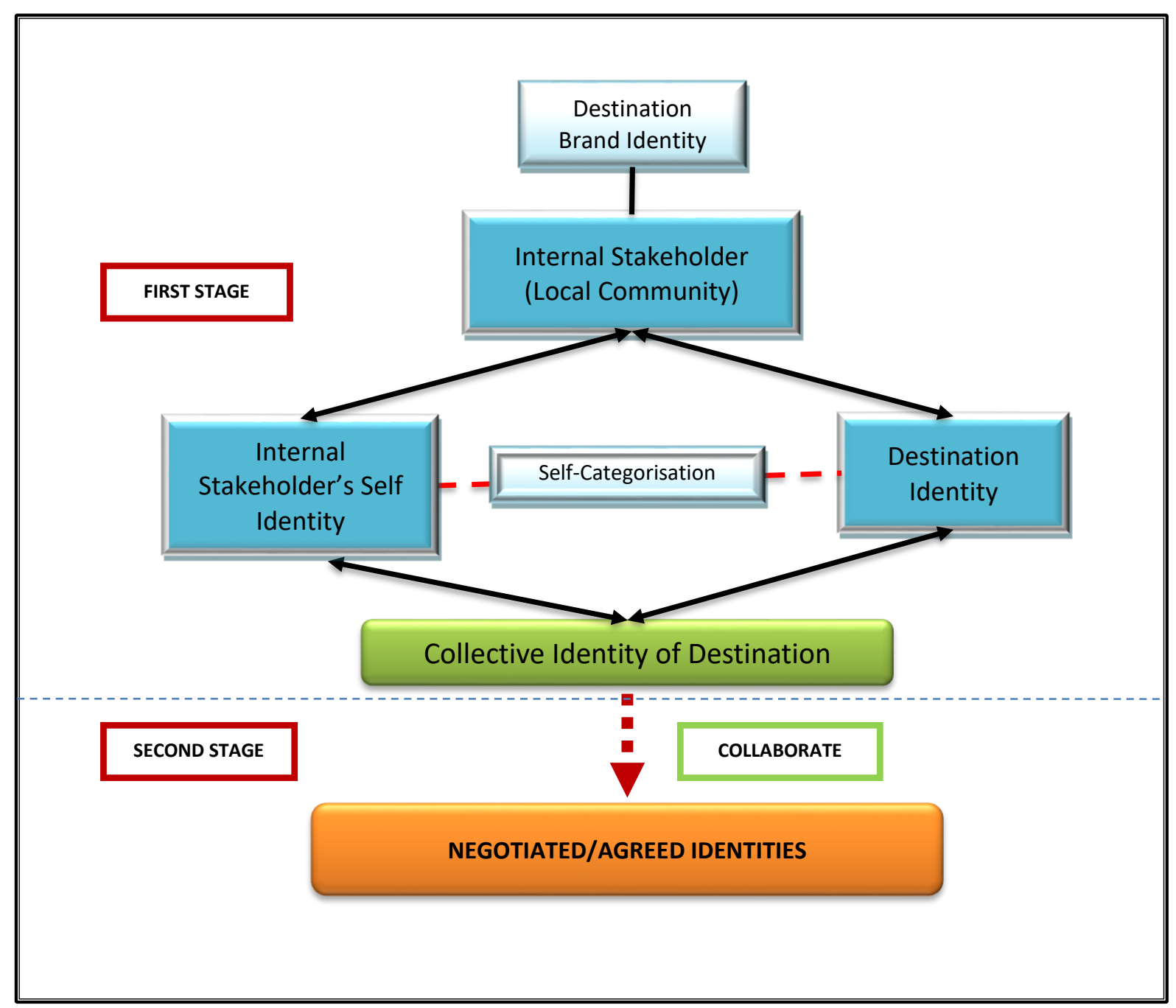

Figure 2: Conceptual Framework in Developing Destination Brand Identity

The residents have the 'power' to influence the sustainability of a destination, their views on the identity of the destination ought to be considered. How they perceive, identify and value the place should be given consideration. Jamrozy (2007) argues that in tourism destinations, the way of life, the economy, all its people and the earth are interrelated in complex ways and influence each other.

In this research, the values held by the residents on the identity of LV will be identified, categorised accordingly, and analysed. It is, therefore, crucial to discover and carefully understand the residents' perception of the identity of the place before any decision of branding the destination can be developed. This helps the management in making sure the perceptions and values of stakeholders are in-line in with communicating those identities. 


\section{METHODOLOGY}

Qualitative research is employed to address the RQ because it allows the interpretation of phenomena in natural settings to make sense of the meanings people bring to a topic being measured (Denzin \& Lincoln, 2011), and to understand the unique interactions in a particular situation (Patton, 2015).

To explore the conceptualisation of the brand identity complexity for a destination (Blichfeldt, 2005; Gilmore, 2002; Hall, 2002), this research seeks to explain why they have come up with the conceptualisations and how they react those identities given by others, and by implication the values perceived by others.

\section{Qualitative Interview}

The face-to-face in-depth interviews and focus group interviews (FGI) are applied to explore the meaning making and value of the destination identity from the micro perspective; and the macro perspective, particularly in how the residents arrive at a consensus on the brand identity.

The interview method helps to explore deeper into how the residents interpret the identity(ies) of the destination and the values held behind their interpretation of those elements of identities. It also allows a two-way conversation initiated by the interviewer in getting information from the participant (Cooper \& Schindler, 2003).

\section{Unit of Analysis}

The unit of analysis comprises the group of - LV's residents which cover all the three districts in the destination. The sample of participants for both stages has been selected purposively (Palys, 2008) in the quest of addressing the research objective and research question developed. The leaders of the local community are considered as the best representative of the residents in explaining the LV's identity(ies).

Nineteen-village headman (Ketua Kampung) and an indigenous community headman (Tok Batin) from the Lenggong District in Hulu Perak, Kuala Kangsar were selected as participants. Since all the village headmen are males, six female participants among the local people were selected to ensure more inclusivity and multidimensionality of insights on the issues being raised. The criteria of selections applied for these female participants are also similar to the village headmen (Table 1).

Table 1: Characteristics of Sample

\begin{tabular}{ll}
\hline \multicolumn{1}{c}{ Method } & \multicolumn{1}{c}{ Sample Characteristics } \\
\hline In-depth Interview & Village Headman \\
& Head/Leader of Cultural or Social Community \\
& Elders with heritage knowledge (based on observation or experience) or \\
& length of residency \\
FGI & Participants from the in-depth interview group \\
\hline
\end{tabular}

\section{Data Collection}

The data collection process was divided into two stages: In-depth interviews to explore how the residents perceive and conceptualise the identity of destination based on their values; and the FGI to analyse the communication between participants and how they respond to other elements of identity given by different participants.

The interviews were implemented in ten days with a duration of between $40-60$ minutes for each participant. The reason was to gauge the identity(s) perceived by different 
residents from this group of stakeholders on the Lenggong Valley and to enable the collection of rich, in-depth and important data (Eisenhardt \& Graebner, 2007; Moore, 2006).

All the interviews were recorded digitally using tape recorders with the permission of the participants. All audio recordings were fully transcribed by the same interviewers while checking or verifying any vague words or points during the interview sessions. The data collected from this first stage were analysed immediately based on all the information pertaining to the research topic discussed.

\section{Method of Analysis}

The descriptive approach of thematic analysis is the most appropriate method to analyse the data that had been gathered to explore the possible identity elements for the LV according to the participants' values. This research used the 6-step framework for thematic analyses initiated by Braun and Clarke (2006).

Thematic analysis is used to identify the significant and fascinating patterns in the data, and hence the themes. The 6-steps highlighted in this framework to analyse qualitative data are (i) familiarisation; (ii) generating initial codes; (iii) searching for themes; (iv) reviewing themes; ( $v$ ) defining and naming themes; and (vi) producing a report.

Based on verbatim transcribed audio, the data were analysed manually. The trend of ideas discovered is sorted out and arranged into different sub-themes by coding each of them. The main themes are then established and the sub-themes that had been coded are categorised. Lastly, the researcher is required to draw his/her own interpretation of the findings and compare them with current literature as well as the theories being applied (Yulia, 2010).

\section{In-Depth Interview Result}

\section{RESULTS AND DISCUSSION}

A set of semi-structured questions is used to solve the research question. The results are presented based on the themes that emerged from semi-structured interview data.

\section{a. Conceptualisation of LV Brand Identity}

In understanding the brand identity of LV from the residents' perspective, their conceptualisation of the LV identity(s) was first explored and examined. The residents were asked to identify elements that they consider to be part of LV's identity. The summary of the coding process to analyse the sub-themes, main themes and values emerged through an indepth interview can be referred to in Figure 3.

There are six sub-themes, five main themes and six values identified. The sub-themes that emerged are (i) lifestyle (foods/cuisines); (ii) environment and recreations, (iii); mores and norms; (iv) agricultural and small enterprises; (v) heritage and history; and (vi) social composition. Based on these six sub-themes, there are five main themes that can be related to each of them, namely (i) local traditions; (ii) unique heritages; (iii) leisure and recreational; (iv) self and community traits; and (v) livelihood. Discussion among the participants can be associated with six values revealed along the transcribing process, namely (i) closeness - part of self/community; (ii) pride in ownership; (iii) different from other community; (iv) sense of empowerment to develop community; (v) self-recognition (self-esteem); and (vi) nostalgia social memory. The findings of each category will be elaborated in more detail in the following section. 


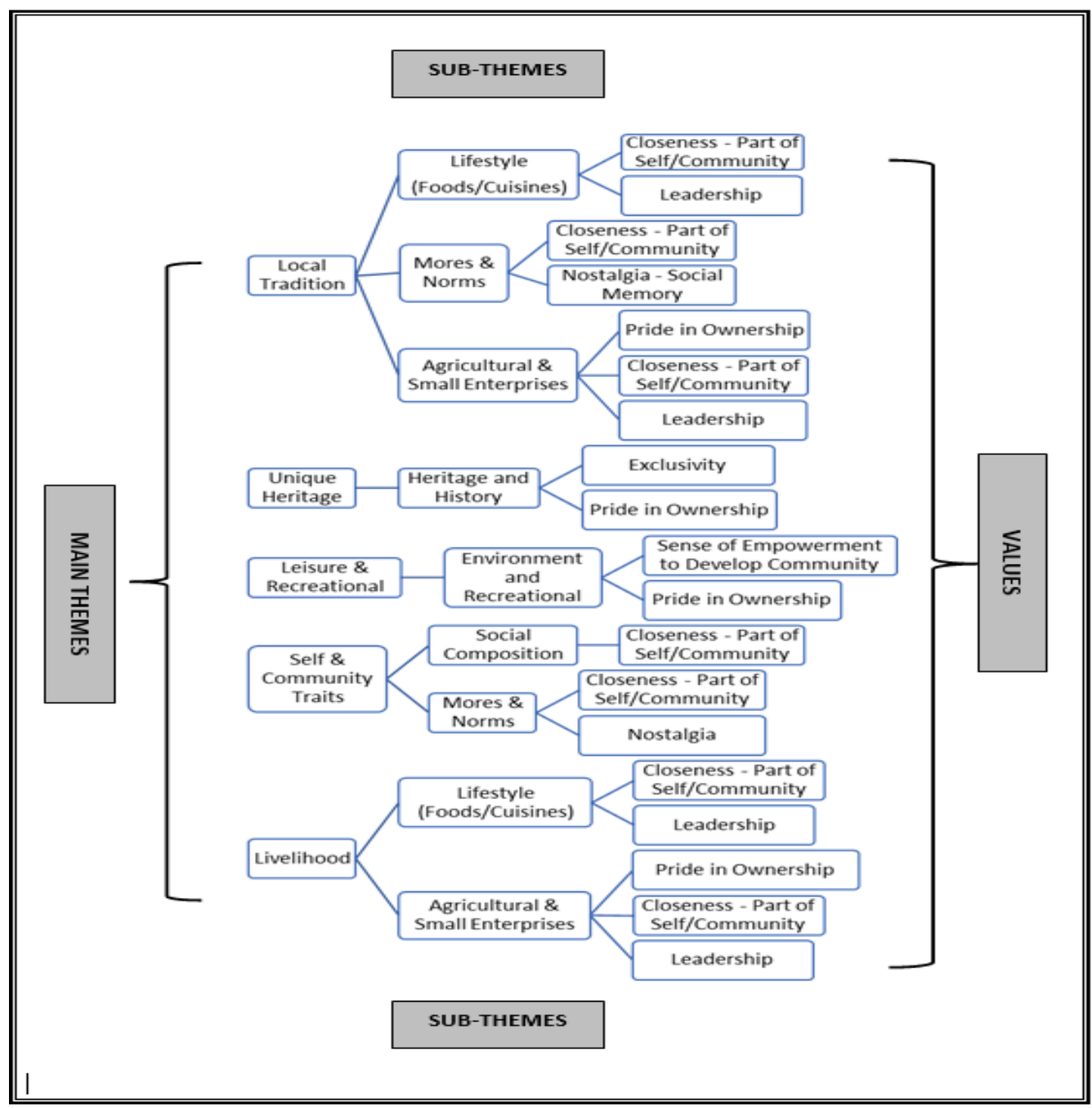

Figure 3: Linkage between Sub-Themes - Main Themes and Sub-Themes - Values

\section{b. Main Themes of Identity and Sub-Themes}

The coding process and the identification of sub-themes led to the five main themes: (i) local traditions; (ii) unique heritage; (iii) leisure and recreational; (iv) self and community traits; and (v) livelihood. Under these five main themes of identity, relevant sub-themes emerged during the coding process. The sub-themes have been categorised accordingly based on the relevancy and appropriateness of the main themes. Based on the findings, the most prominent identity element highlighted by the participants is a lifestyle (foods/cuisines), then followed by agricultural and small enterprises, heritage and history, environment and recreations, mores and norms, and social composition. Details of these main themes are summarised in Figure 4: 


\begin{tabular}{|ll|}
\hline MAIN THEMES & SUB THEMES \\
Local Traditions & Lifestyle (Foods/Cuisines) \\
& Mores \& Norms \\
& Agricultural \& Small Enterprise \\
Unique Heritage & Heritage \& History \\
Leisure and Recreational & Environment \& Recreations \\
Self \& Community Traits & Social Composition \\
& Mores \& Norms \\
Livelihood & Lifestyle (Foods/Cuisine) \\
& Agricultural \& Small Enterprises \\
\hline
\end{tabular}

Figure 4: Main Themes of Identity and Sub-Themes

\section{c. Values Behind the Perceived Identities of $L V$}

Based on the participants' feedbacks in explaining the attractions and identity of their village and LV, six values are discovered. The values are (i) closeness - part of the self/community; (ii) pride in ownership; (iii) exclusive; (iv) sense of empowerment to develop community; (v) nostalgia; and (vi) leadership. Figure 5 summarises the relationship between the values and their relevant sub-themes exposed during the interview.

\begin{tabular}{|ll|}
\hline VALUES & SUB THEMES \\
Closeness - Part of Self/Community & Lifestyle (Foods/Cuisines) \\
& Mores \& Norms \\
& Social Composition \\
Exclusivity & Agricultural \& Small Enterprises \\
Sense of Empowered to Develop Community & Heritage \& History \\
Nostalgia - Social Memory & Environment \& Recreations \\
Pride in Ownership & Mores \& Norms \\
& Environment \& Recreations \\
& Agricultural \& Small Enterprises \\
Leadership & Heritage \& History \\
& Lifestyle (Foods/Cuisine) \\
& Agricultural \& Small Enterprises \\
\hline
\end{tabular}

Figure 5: Correlationship between Values and Sub-Themes

\section{FGI Finding}

The FGI was conducted to analyse the identity elements among the participants as the stakeholder of Lenggong and to determine how the participants representing the larger LV community, negotiate and identify the most salient identity among previously identified elements during the in-depth interviews. In this process, the participants were obliged to think about the identity of LV as a whole, above and beyond their own villages.

About 5 - 6 headmen were grouped at one time. The duration between $60-90$ minutes was allocated for each group to complete all the questions prepared. A set of semi structured questions was developed to answer the research question.

\section{a. Negotiating the Salient Identity of $L V$}

Figure 6 presents the identities that have been discussed and highlighted by the participants during the process of collaboration. At the bottom of Figure 6 are the salient identities that resulted from the negotiation process in each focus group. Based on Figure 6, only a few identities of LV were raised and debated by participants during the FGI, when instructed to identify the core/salient identity that will be representing LV, regardless of the number of villages available in LV: 


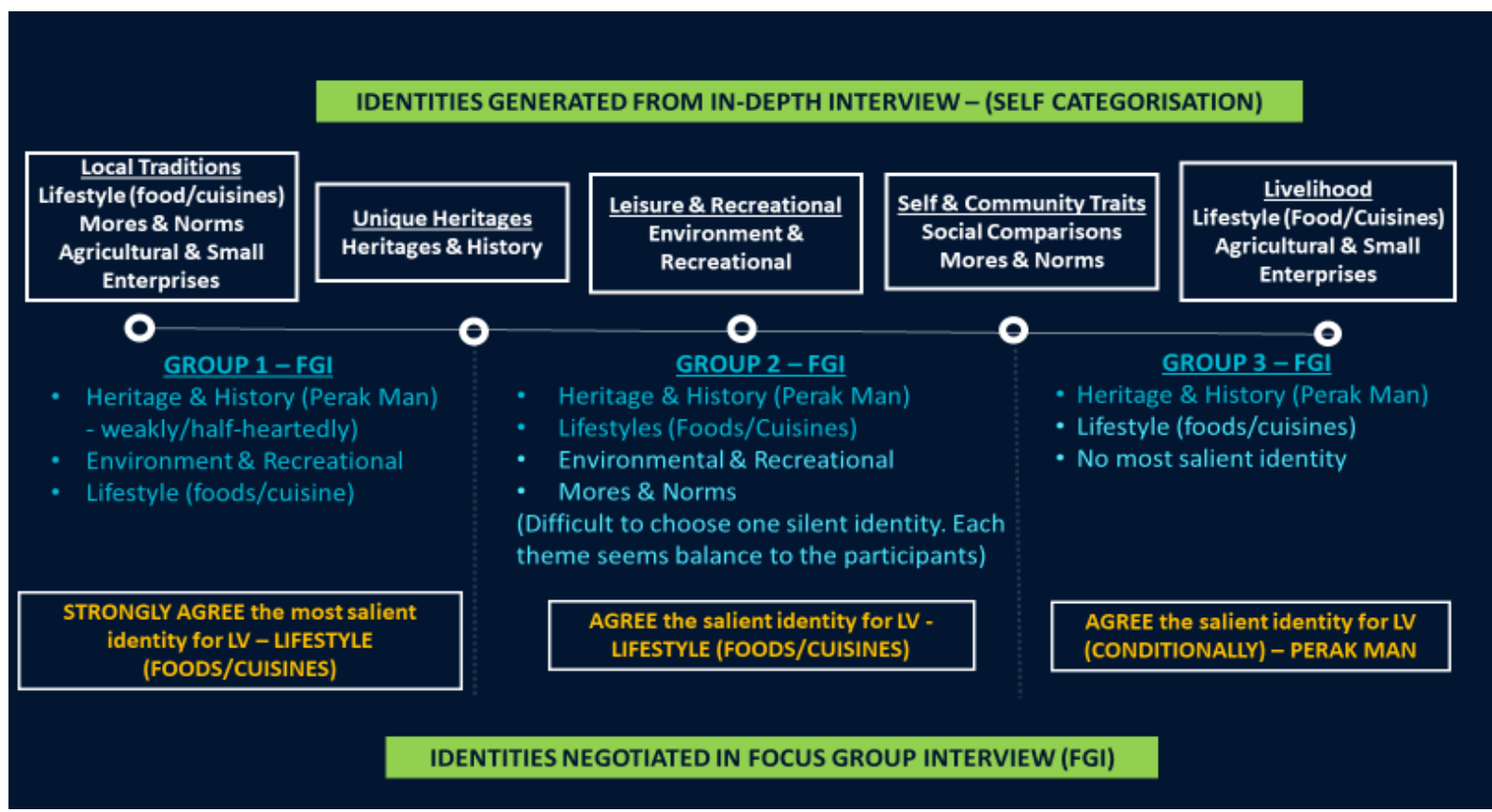

Figure 6: Negotiated Salient Identity for Lenggong Valley

\section{Discussion of the Findings}

Examined through the lens of the stakeholder and social identity theories, and guided by Kapferer's (2012) identity prism, the study has ascertained themes of identity elements in identifying core and extended identities and values that underscore those identities as perceived by the residents. The study reveals the crucial underlying thought processes as well as self and community values that underscore their association with the destination brand identity. When residents were interviewed individually, the findings reveal that a heritage destination is complex. There are multi layers of meanings valued for varied reasons and attached to multiple self-identities by the participants.

During the in-depth interviews, the destination identities emerged largely as a " $m e$ " (internal) versus "you" (external) dichotomy and much less of an "us" (in-group) versus "them" (out-group) for the members of the local community. These identities and the attached values were deliberated from largely a micro perspective, looking at the world from the lens of an individual within a community. The "we"-ness were much less observed in this phase compared to the second phase. Nevertheless, this phase of the study importantly revealed that the self-identity of individuals has a significant influence on how residents conceptualise a destination brand identity, and how their own personal values (as reflected in their self-identities) and the community values (as reflected in the social identities) are interrelated in that conceptualisation.

In the second phase of the study, when the residents were interviewed in a focus group, the discussion on the brand identities were deliberated on a more macro perspective, moving from a discussion of "self" versus others in the community and eventually to a discussion of "us" versus "them" (for example, other communities, archaeologists and tourists). In general, the findings revealed that from the perspective of the local community a destination brand identity ideally needs to reflect both the individual resident's self-identity and social identity. However, when discrepancies between self and social identities arise, interestingly the residents reflected on the "us" and "them" as opposed to "us" versus "them" 
dichotomy as would have been predicted through the lens of the social identity theory. The reflection of " $u s$ " and "them" further concretise the 'we'-ness of the local community when the external parties such as the tourists are thrown into the equation. These negotiations and renegotiations, hinged on self ( $m e$ ) and social identities (us) as well as the interest of tourists (them), are integral to the resident's mutual agreement to the brand identity of LV. The residents eventually agreed that Perak Man should be the core identity of Lenggong. By doing this they will be able to communicate the most attractive and unique feature of LV compared to other destinations, and thus attract visitors to LV.

Interestingly, this decision has an ulterior motive; in spite of their lack of knowledge of Perak Man, their intention was to first attract tourists in and then interact with them through what they value most, as reflected in the extended identity including lifestyle (foods/cuisines), agricultural and small enterprises, history, environment and recreations, mores and norms and social compositions. The specific discussions based on the research question is presented in the following sections.

\section{Residents' Conceptualisation of LV's Destination Identity \\ a. Identity Elements and Values}

Six sub-themes emerged from the analysed data, and five main themes were established to represent the elements of identity as perceived by the participants. The themes were local tradition, livelihood, unique heritage, leisure and recreational, and self and community traits. The sub-theme of lifestyle (foods/cuisines) grouped under the main theme of local tradition, is the most frequent element of identity voiced by the participants, followed by agricultural and small enterprises, heritage and history, environment and recreations, mores and norms and social composition. In this phase, participants were basically aligning themselves to different sub-groups in the community (e.g. Pattani) based on their respective self-identities.

Lifestyle (foods/cuisines) and Agricultural and Small Enterprises were frequently and consistently mentioned by the participants because both closely represented who they were and what they normally practiced. Those two elements were very familiar to them and thus they were able to elaborate and explain them comprehensively when enquired. These two elements of identity explained the concepts of " $m e$ " and "you". As highlighted in the theory of social identity, individuals will categorise themselves with a group that has similarity with the self and termed as 'in-group'. On the other hand, the opposite perspective will come into the equation when the individuals noted that those identity elements were not describing them, hence deciding that these were "you", an 'out-group' that was dissimilar with the self (Haslam et al., 2011; McLead, 2008; Shang, Reed \& Croson, 2008).

The values that emerge behind residents' positive interpretations of the identity elements are the sense of closeness. Those identity elements portrayed the part of themselves and their society. Values have been said to be an integral part of identity. It is a cohesive core that helps and influences the formation of social identity (Hitlin, 2003). Most of the residents responded similarly to these identity elements, specifically the sub-theme of lifestyle (foods/cuisines) because of the deeply held values as rural people (villagers) that are often linked to things that are more traditional, one of which is food and cuisines.

Considering values are the guiding principles in determining the individual's goals, behaviours and evaluations (Bardi \& Schwartz, 2010; Hills, 2010; Jain, Singh \& Rankawat, 2011), it became clear in the reflection of the process in the interviews on how the term "you" as an 'out-group' was formed. Initially, the residents did not feel sub-themes like heritage and 
history, mores and norms, grouped under the main themes of unique heritage and self, and community traits as something that could represent their identity of a place. It was rare for the residents to mention about the renowned and much-publicized 'trademarks' of LV, namely, the archaeological elements (the Perak Man and other archaeology sites) when conceptualising their place identity(s), regardless whether they from the core or buffer zones.

The values underlying the residents' evaluation or perception of the Perak Man and archaeological sites are their exclusivity and pride in ownership. However, the residents do see positive values in these elements. Although archaeological elements of identity were not accepted as the identity of the place due to the reasons being mentioned and their beliefs in Islam, the residents appreciated the value of these archaeological elements to LV and its people. As such, it could be interpreted that pride in ownership had helped to value the archaeological elements.

This first phase of data collection focused on the residents' self-categorising and conceptualising of their identity elements that were most relevant to the self. During the process, these self-categorisation and conceptualisation were aligned to their perceptions of what were "me", "you", "us" and "them". The residents were trying to accommodate the selfidentity with the groups' identity, prioritising identities that are similar over those that are not. The priority given during this process focused more on the residents' self-identity, rather than the broader scope as a group. Understanding one's identity in relation to social identity is crucial in asserting one's personal values within the bigger picture. From the point of brand identity development, self-identities should be part of the consideration process to ensure residents have a sense of ownership and pride. In the following section, the negotiations among the residents in conceptualising the brand identity for the destinations are discussed.

\section{b. Collective Identity ("We"-ness)}

It is widely acknowledged by the media and state-sanctioned bodies that LV's recognition as a national and world heritage site is linked to the discovery of prehistoric human settlement. Perak Man in particular, the first prehistoric hominid discovered in Lenggong, stood out as one of the most identifiable heritage of Lenggong. However, the findings from the in-depth interview indicate otherwise; Perak Man was not what stood out as the identity element among the residents most recognised. The Perak Man was only mentioned in passing and without much conviction and quickly linked to the open caves around Lenggong and other historic sites.

The findings on Perak Man was not reflective of what had been extolled by the mass media and state-sanctioned bodies. While the external stakeholders lauded Perak Man, the Lenggong community felt removed from it. On the one hand, they accepted Perak Man as a national heritage as explained by the authorities but found it personally hard to accept or even relevant to their immediate community. When probed on the identity of Lenggong, only two headmen mentioned Perak Man in passing when they were highlighting other elements of identity such as the caves and historical sites in Lenggong. When probed further he admitted that this heritage was relatively new and unfamiliar to them. They were introduced to Perak Man about ten years back and still struggling to understand who he is.

The participants made it clear that Perak Man, as a prehistoric human was not able to represent their place and symbolise who they are. For that matter, they did not even know who and how to describe the Perak Man is in detail. They felt it inappropriate that the Lenggong identity is represented by something that the community itself could not relate to. They had a negative stand on the Perak Man which they believed was incompatible with 
Islamic teaching. To them, Perak Man belonged to the others and "them" whose views were not necessarily aligned to theirs.

As forewarned by Kapferer (2012) on the importance of 'physique', the lack of physical presence of Perak Man had made it difficult for the community to relate. Perak Man's identity was mostly learned from descriptions in the Lenggong gallery without his actual physical presence. The participants lamented that they had very low accessibility to Perak Man, and had little say about him.

Interestingly, despite the rejection of Perak Man as a key identity element of Lenggong, it still drew positive emotion among the residents. The disconnections are evidently a result of being unfamiliar with the technical details of Perak Man. The Perak Man is an archaeological heritage that requires certain knowledge, skills and expertise to be understood. It is one of the oldest evidence of human civilization who's beyond the cognitive ability of the village community, it was beyond them to relate and position themselves in this history of human evolution. Efforts to share and distribute any information pertaining to it must, therefore, be initiated from the top leaders or relevant bodies such as the state sanction authorities. However, the exclusivity of the Perak Man and its influence on Lenggong being designated as a World Heritage Site, has in turn, granted positive impacts to the residents. This is supported by the findings in both stages of data collection.

Similar expressions and moods could be traced during the FGI. Although the first and second groups of the FGI had decided to choose the sub-theme of lifestyle (foods/cuisines) as the salient identity for Lenggong, yet they remained very appreciative of the impact of the archaeological heritage to others, that it was a part of the history of human civilization that had the potential to make others know and recognise Lenggong. Their willingness to accept Perak Man as part of the identity was underscored by instrumental values and goals; the participants believed the heritage is valuable and could be leveraged to bring positive economic impact for Lenggong by drawing in the tourists. In reference to the affective elements of the social identity perspective, positive emotions attached to a person on any identity or group such as pride and enthusiasm are capable of influencing the relationship with it (Bagozi \& Dholakia, 2002; McAlexander, Schouten \& Koening, 2002). In the case of Lenggong, although most of the participants are quite reluctant to admit, yet they still appreciated the heritage. The positive emotions elicited in the discovery of Perak Man could be linked to the participants' enhanced self-esteem.

The findings revealed that economic development and economic survival are the terminal values that are highly crucial to the community. Their most important responsibility was to ensure that each household under their purview could put food on the table daily and that issues of identities were far less important unless they could prove instrumental in ensuring the economic sustainability of the residents. Hence, their lack of interest in identities that bear little significance to the economic survivability. As highlighted in the social identity theory (Abrams \& Hogg, 2006; Bar-Tal, 2009 \& 2014; Fombelle, et al., 2012; Shiu \& Hassan, 2016; Turner, Mcgowan, McLeod, 2008), a person derives his/her self-esteem not only individually, but also from group identities. If an identity is perceived to have negative qualities to the group, they would try to stay away and consider it as an identity for the 'outgroup' rather than 'in-group' (Abrams \& Hogg, 2006; Fombelle, et al., 2012; Guan \& So, 2016; McLead, 2008; Tajfel, 2010). 
The FGI however, uncovered several issues that need to be resolved in order to strengthen the Perak Man as the identity of Lenggong. Quite a number of efforts need to be done on how to establish a strong relationship between the residents of Lenggong with the Perak Man for them to comfortably accept it as their collective identity. A proper plan needs to be in place immediately to ensure the gap between ' $u s$ ' and 'them' can be bridged and for the idea of 'we-ness' (i.e. encapsulating the residents and the tourists) can be established.

\section{CONCLUSION}

An examination of the resident's conceptualisation and interpretation of the brand identity of the Lenggong Valley UNESCO World Heritage Sites, through the lenses of stakeholder and social identity theories, has revealed the importance and significance of engaging the residents in the destination brand identity development process. The study most importantly shows that the bottom up approach of conceptualising destination brand identity from the perspective of the residents is advantageous in gaining a value-rich identity that is highly meaningful to the community, thus resulting in strong stewardship for future tourism development and in turn result in a potentially richer experience for the part of the tourists due to the strong evocation of a sense of place.

\section{BIODATA}

Norfardilawati Musa is a senior lecturer for Cluster of Education and Social Sciences (previously Faculty of Applied and Social Sciences) at Open University Malaysia, Kuala Lumpur. Email: norfardilawati@oum.edu.my

Shuhaida Md Noor, PhD is a senior lecturer at the School of Communication, Universiti Sains Malaysia. Email: shuhaida@usm.my 


\section{REFERENCES}

Aaker, D. A. (1992). Strategic market management (3rd. Ed). New York: John Wiley \& Sons Inc.

Aaker, D. A. (2010). Building strong brands. New York: Free Press.

Aaker, D. A. (2014). Aaker on branding: 20 principles that drive success. New York: Morgan James Publishing

Abrams, D., \& Hogg, M. A. (2006). Social identifications: A social psychology of intergroup relations and group process. London: Routledge.

Anholt S. (2007) The theory of competitive identity. London: Macmillan.

Anholt, S. (2006). Public diplomacy and place branding: Where's the link?. Place Branding, 2(4), 271-275.

Avraham, E., \& Ketter, E. (2008) Media strategies for marketing places in crisis improving the image of cities, countries and tourist destinations. Oxford: Butterworth-Heinemann.

Baker, B. (2007). Destination branding for small cities: The essentials for successful place branding. Portland, $\mathrm{OH}$ : Creative Leap Books.

Balakrishnan, M. S. (2009). Strategic branding of destinations: A framework. European Journal of Marketing, 43(5/6), 611-629.

Bardi, A., Lee, J. A., Towfig, N., \& Souta, G. (2009). The structure of intraindividual value change. Journal of Personality and Social Psychology, 97(5), 913 - 929.

Bardi, A., \& Goodwin, R. (2011). The dual route to value change: Individual processes and cultural moderators. Journal of Cross-Cultural Psychology, 42(2), 271 - 287.

Bar-Tal, D. (2014). Collective memory as social representation. Social Representation, 23, 1.70-1.96.

Beritelli, P. (2010). Cooperation among prominent actors in a tourist destination. Annals of Tourism Research, 38, 2.

Blain, C., Levy, S. E., \& Ritchie, J. R. B. (2005). Destination branding: Insights and practices from destination management organisations. Journal of Travel Research, 43(4), 328-338.

Bornhorst, F., Gupta, S., \& Thornton, J. (2009). Natural resource endowments and the domestic revenue effort. European Journal of Political Economy, 25, 439-446.

Bornhorst, T., Brent, R., \& Sheehan, L. (2010). Determinants of tourism success for DMOs \& destinations: An empirical examination of stakeholders' perspectives. Tourism Management, 31(5).

Bramwell, B., \& Sharman, A. (1999). Collaboration in local tourism policy making. Annals of Tourism Research, 26(2), 392-415.

Buhalis, D. (1999). Tourism on the Greek islands: Issues of Peripherality, Competitiveness and Development. International Journal of Tourism Research, 1, 341 - 358.

Buhalis, D. (2000). Marketing the competitive destination of the future. Tourism Management, 21, 97-116.

Cosma, S., Urcan, A., \& Bota, M. (2010). Study about brand identity for Romania as a tourist destination. Proceedings of the 5th WSEAS International Conference on Economy and Management Transformation (Volume I).

Dinnie, K. (2011). Introduction to the theory of city branding. In Dinnie K. (Ed.), City branding. London: Palgrave Macmillan.

Department of National Heritage. (2012). Archaeological heritage of the Lenggong Valley - A UNESCO world heritage site. Retrieved Jan. 6th, 2014, from http://lenggong.heritage.gov.my/index.php/about/archaeological-heritage 
Dredge, D. (2006). Networks, conflict and collaborative communities. Journal of Sustainable Tourism, 14(6), 562-581.

Fujita, M., Harrigan, P., \& Soutar, N. G. (2018). Capturing and co-creating students experiences in social media: A social identity theory perspective. Journal of Marketing Theory and Practice, 26, 55-71.

Fyall, A. (2011). Destination management: Challenges and opportunities. Wang, Y., \& Pizam, A. (Eds.), Destination marketing and management: Theories and applications 2011 (pp. 340-357). Wallingford: CABI. doi: 10.1079/9781845937621.0340

Fyall, A., \& Garrod, B. (2005). Tourism marketing: A collaborative approach. Clevedon: Channel View Publications.

Gilmore, F. (2002). Branding for success. In N. Morgan, A. Pritchard \& R. Pride (Eds.), Destination branding: Creating a unique destination proposition (pp. 57-65). Oxford, UK: Butterworth Heinemann.

Guan, M., \& So, J. (2016). Influence of social identity on self-efficacy belief through perceived social support: A social identity theory perspective. Communication Studies, 67, 588604.

Hall, C. M., \& Jenkins, J. (1995). Tourism and public policy. London: Routledge.

Hall, C. M. (2000). Tourism planning: Policies, processes and relationships. Harlow: Prentice Hall.

Hankinson, G. (2004). Relational network brands: Towards a conceptual model of place brands. Journal of Vacation Marketing, 10(2), 109-121.

Hankinson, G. (2004). The brand images of tourism destinations: A study of saliency of organic images. Journal of Product and Brand Management, 13(1), 6-14.

Hankinson, G. (2007). The management of destination brands: Five guiding principles based on recent developments in corporate branding theory. Journal of Brand Management, 14(3), 240-254.

Hankinson, G. (2009). Managing destination brands: Establishing a theoretical foundation. Journal of Marketing Management, 25(1-2), 97-115.

Haslam, S. A., Peters, K. Steffens, N. K., \& Reicher, S. D. (2016). 5R manual: Social identity and groups network. Brisbane: University of Queensland.

Haslam, S. A., Reicher, S. D., \& Platow, M. J. (2011). The new psychology of leadership: Identity, influence and power. London: Psychology Press.

Hernández, B., Hidalgo, M. C., Salazar-Laplace, M. E., \& Hess, S. (2007). Place attachment and place identity in natives and non-natives. Journal of Environmental Psychology, 27(4), 310-319.

Hogg, M. A., \& Vaughan, G. M. (2002). Social psychology (3rd ed.). London: Prentice Hall.

Hogg, M. A., \& Terry, D. J. (2001). Social identity processes in organizational contexts. Philadelphia: Psychology Press.

Hogg, M. A., \& van Knippenberg, D. (2003). Social identity and leadership processes in groups. In M. P. Zanna (Ed.), Advances in experimental social psychology (Vol. 35, pp. 1-52). San Diego: Academic Press

Hogg, M. A., \& Abrams, D. (1988). Social identifications: A social psychology of intergroup relations and group processes. London: Routledge.

Ind, N. (2003). Beyond Branding. New York: Kogan Page Limited.

Jamal, T., \& Getz, D. (1995). Collaboration theory and community tourism planning. Annals of Tourism Research, 22(1), 186-204. 
Jamal, T., \& Getz, D. (2005). Community roundtales for tourism related conflicts: The dialectics of consesnsus and process structures. In Bramwell, B., \& Lane, B. (Eds.), Tourism collaboration and partnerships: Politics, practice and sustainability (pp. 159-182). Clevedon: Channel View Publications.

Kapferer, J. N. (2012). New strategic brand management: Advanced insights and strategic thinking. Retrieved from http://unitec.eblib.com.au/patron/FullRecord.aspx?p=871552

Kapferer, J. N. (1997). Strategic brand management: Creating and sustaining brand equity long term (2nd ed.). London: Kogan-Page Ltd.

Kapferer, J. N. (1998). Strategic Brand Management. London: Kogan Page.

Kavaratzis, M., \& Ashworth, G. (2005). City branding: An effective assertion of identity or a transitory marketing trick? Tijdschrift voor Economische en Sociale Geografie, 96(5), 506-514.

Keller, K. L. (2012). Strategic brand management: Building, measuring and managing brand equity. Upper Saddle River, NJ: Prentice Hall.

Konecnik, M., \& Go, F. (2008). Tourism destination brand identity: The case of Slovenia. Journal of Brand Management, 15(3), 177-189. doi: 10.1057/palgrave.bm.2550114

Kotler, P., \& Pfoertsch, W. (2010). Ingredient branding: Making the invisible visible. Heidelberg: Springer.

Kotler, P., \& Gertner, D. (2002). Country as brand, product, and beyond: A place marketing and brand management perspective. Journal of Brand Management, 9(4-5), 249-261.

Kotler, P., \& Gertner, D. (2011). A place marketing and place branding perspective revisited. In Morgan, N., Pritchard, A., \& Prode, R. (Eds.), Destination brands: Managing place reputation (p. 33-53). Oxford: Butterworth Heinemann, Elsevier.

Kotler, P., Haider, D., \& Rein, I. (2002). Marketing places: Attracting investment, industry and tourism to cities, states and nations. New York: Free Press.

Lemmetyinen, A., \& Go, F. M. (2009) The key capabilities required for managing tourism business networks. Tourism Management, 30, 31-40.

March, R., \& Wilkinson, I. (2009). Conceptual tools for evaluating tourism partner-ships. Tourism Management, 30(3), 455-462.

Marzano, G., \& Scott, N. (2009). Power in destination branding. Annals of Tourism Research, $36(2), 247 \mathrm{e} 267$.

Marzano, G., \& Scott, N. (2006). Destination branding: Conceptualization of collaboration within a problem domain. Paper presented to ATLAS Asia Pacific Conference 'Tourism After Oil'. Dunedin, New Zealand.

Mazzarol, J., Sweeney, J., \& Soutar, G. (2007). Conceptualising word-of-mouth activity, triggers and conditions: An exploratory study. European Journal of Marketing, 41(1112), $1475-1494$.

McComb, E., Boyd, S., \& Boluk, K. (2016). Stakeholder collaboration: A means to the success of rural tourism destinations? A critical evaluation of the existence of stakeholder collaboration within the mournes, Northern Ireland. Tourism and Hospitality Research, 17(3), 286-297.

McLead, S. A. (2008). Social identity theory. Retrieved from www.simplypsychology.org/social-identity-theory.html 
Morgan, D. L. (2007). Paradigms lost and pragmatism regained: methodological implications of combining qualitative and quantitative methods. Journal of Mixed Methods Research, 1(1), 48-76.

Morgan, N., Pritchard, A., \& Pride, R. (2011). Tourism places. Brands and Reputation Management, 3-19.

Morgan, N. J., Pritchard, A., \& Piggott, R. (2003). Destination branding and the role of stakeholders: The case of New Zealand. Journal of Vacation Marketing, 9(3), 285-299.

Morgan, N., Pritchard, A., \& Pride, R. (2014). Destination branding: Creating the Unique Destination Proposition (2nd ed.). Oxford, UK: Butterworth-Heinemann.

Palmer, A., \& Bejou, D. (1995) Tourism destination marketing alliances. Annals of Tourism Research, 22, 616-629.

Palys, T. (2008). Purposive sampling. In L. M. Given (Ed.), The Sage encyclopedia of qualitative research methods (Vol. 2, pp. 697-8). Los Angeles: Sage.

Pforr, C. (2006). Tourism administration in the northern territory in the era of CLP governance (1978-2001). Australian Journal of Public Administration, 65(1), 61-74.

Reed, A. (2002). Social identity as a useful perspective for self-concept-based consumer research. Psychology Marketing, 19, 235-266.

Shang, J., Reed, A. \& Croson, R. (2008). Identity congruency effects on donations. American Marketing Association, XLV, 351-361.

Sheehan, L. R., \& Ritchie, J. R. B. (2007). Destination stakeholders, exploring identity and salience. Annals of Tourism Research, 32(3), 711-734.

Stets, E. J., \& Burke, P. J. (2000). Identity theory and social identity theory. Social Psychology Quarterly, 63(3), 224-237.

Tajfel, H. (Ed.). (2010). Social identity and intergroup relations. Cambridge: Cambridge University Press.

Tajfel, H., \& Turner, J. C. (1979). An integrative theory of intergroup conflict. London: Routledge.

Tajfel, H., \& Turner, J. C. (1986). The social identity theory of inter-group behaviour. In S. Worchel \& L. W. Austin (Eds.), Psychology of intergroup relations. Chicago: NelsonHall.

Tajfel, H. (1982). Social psychology of intergroup relations. Annual Review of Psychology, 33, 1.

Turner, J. C., Hogg, M. A., Oakes, P. J., Reicher, S. D., \& Wetherell, M. S. (1987). Rediscovering the social group: A self-categorisation theory. New York: Basil Blackwell.

Upadhyaya, M. (2012). Influence of destination image and destination personality: An empirical analysis. Journal of Marketing \& Communication, 7(1), 40 - 47.

Waayers, D., Lee, D., \& Newsome, D. (2012). Exploring the nature of stakeholder collaboration: A case study of marine turtle tourism in the Ningaloo region, western Australia. Current Issues in Tourism, 15, 7.

Wheeler, F., Frost, W., \& Weiler, B. (2011). Destination brand identity, values and community: A case study from rural Victoria, Australia. Journal of Travel \& Tourism Marketing, 28, 13-16.

Wheeler, D., \& Sillappaa, M. (1997). In Carroll, B. A., \& Buchholtz, K. A. (2006) (Eds.), Business \& society: Ethics and stakeholders management (6th ed.). New York: South-Western.

World Tourism Organisation (WTO). (2004). Indicators of sustainable development for tourism destinations: A guidebook. Madrid: WTO. 